\title{
IMPLEMENTASI METODE PROMETHEE DALAM PENENTUAN PENERIMA BANTUAN ZAKAT PADA MAHASISWA
}

\author{
Rima Aprilia ${ }^{1}$, Rina Widyasari ${ }^{2}$ \\ ${ }^{1,2}$ Program Studi Matematika, Universitas Islam Negeri Sumatera Utara \\ Jln.IAIN No.1 Medan \\ rima_aprilia@uinsu.ac.id,rina_widyasari@uinsu.ac.id
}

\begin{abstract}
Abstrak - Pada masa pembayaran uang kuliah tunggal (UKT) setiap semester, selalu dihadapkan dengan permasalahan mahasiswa berprestasi namun tidak mampu membayar biaya pendidikan. Oleh karena itu, pihak universitas memberikan solusi untuk memberikan zakat yang diperoleh dari dosen kepada mahasiswa berprestasi dan tidak mampu melalui proses pemilihan. Selama ini, proses pemilihan mahasiswa masih dilakukan secara manual tidak menggunakan sistem atau program. Sehingga pemerataan penerima bantuan pendidikan (zakat) dinilai tidak tepat sasaran. Hal ini tentu akan menjadi masalah ketidakadilan secara terus menerus, apalagi saat ini sudah memasuki era digital 4.0, semua proses menggunakan suatu sistem digital. Pemberian bantuan dana pendidikan berupa zakat harus berdasarkan aturan-aturan yang telah ditetapkan,dalam hal ini berupa aturan tersebut berupa kriteria yang ditetapkan yaitu IP mahasiswa, penghasilan orang tua, jumlah saudara kandung, jumlah tanggungan orang tua, semester, dan lain-lain. Tujuan dari penelitian ini adalah untuk menguji apakah metode Promethee merupakan metode yang dapat menyelesaikan permasalahan tersebut. Selain itu, penelitian ini juga membentuk suatu flow chart sistem pemilihan penerima bantuan pendidikan dengan metode Promethee. Hasil penelitian ini menunjukkan permasalahan penentuan penerima bantuan zakat oleh mahasiswa dapat diselesaikan dengan menggunakan metode PROMETHEE. Promethee (Preference Ranking Organization for Enrichment Evaluation), Metode ini tepat untuk menentukan penerima bantuan zakat.
\end{abstract}

Kata Kunci - Sistem Pendukung Keputusan, Promethee, Zakat

Abstract-During the payment of a single tuition fee (UKT) every semester, students are always faced with the problem of outstanding students but unable to pay tuition fees. Therefore, the university provides a solution to give zakat obtained from lecturers to outstanding and underprivileged students through the selection process. So far, the student selection process is still done manually, not using a system or program. So that the distribution of educational aid recipients (zakat) is considered not on target. This will certainly be a continuous problem of injustice, especially now that we have entered the digital era 4.0, all processes use a digital system. The provision of educational fund assistance in the form of zakat must be based on established rules, in this case the rules are in the form of established criteria, namely student IP, parental income, number of siblings, number of dependents of parents, semester, and others. The purpose of this study is to test whether the Promethee method is a method that can solve these problems. In addition, this research also forms a flow chart for selecting recipients of educational assistance using the Promethee method. The results of this study indicate that the problem of determining recipients of zakat assistance by students can be solved using the PROMETHEE method. Promethee (Preference Ranking Organization for Enrichment Evaluation), This method is appropriate for determining recipients of zakat assistance.

Keyword - Decision Support System, Promethee, Zakat

\section{PENDAHULUAN}

Universitas Islam Negeri Sumatera Utara merupakan salah satu universitas negeri di bawah Kementerian Agama. Semua kegiatan akademik dan non akademik di perguruan tinggi (PT) ini menganut nilai-nilai keislaman. Salah satu upaya yang dilakukan PT ialah mengadakan zakat yang diperoleh dari pendapatan pokok dan tunjangan dari setiap dosen dan pegawai sebesar 2,5 persen setiap bulannya. Zakat ini dikumpulkan oleh Unit Penerima Zakat (UPZ).
Karena pada setiap semesternya, banyak mahasiswa yang tidak mampu membayar uang kuliah tunggal (UKT), sehingga zakat ini ditujukan untuk memberikan bantuan pendidikan kepada mahasiswa beprestasi dan kurang mampu berupa beasiswa. Selain itu, zakat disalurkan untuk kegiatan amal lainnya.

Setiap mahasiswa yang ingin mendapatkan bantuan tersebut, harus memenuhi aturan yang telah ditentukan. Aturan tersebut dituangkan dalam kriteriakriteria yang akan digunakan dalam 
memodelkan/merancang sistem. Kriteria yang ditetapkan adalah nilai indeks prestasi akademik, penghasilan orang tua, jumlah saudara kandung, jumlah tanggungan orang tua, semester, dan lain-lain. Dengan demikian, tidak semua orang yang mendaftar sebagai calon penerima zakat akan diterima, hanya yang memenuhi kriteria-kriteria saja yang dapat menerima bantuan dana pendidikan berupa zakat tersebut.

Namun, dalam pelaksanaannya, pemilihan penerima bantuan pendidikan (zakat) masih menggunakan cara manual yang tidak efisien terlebih lagi kalau ada unsur nepotisme di dalamnya. Pemilihan di antara ribuan mahasiswa dengan kriteria yang banyak membutuhkan suatu sistem praktis, apalagi saat ini merupakan era digital 4.0. Oleh karena itu, untuk membangun suatu keadilan dan pemerataan dalam pembagian zakat serta efisiensi, maka penelitian ini mengajukan suatu pengujian metode Promethee serta membangun suatu algoritma untuk menyelesaikan masalah tersebut.Pengambilan keputusan adalah proses memilih diantara berbagai alternatif yang bertujuan untuk mencapai satu atau beberapa tujuan. Sistem pengambilan keputusan terbagi dalam 4 tahapan yaitu intellegence, design, choice dan implementation. tahap 1 sampai 3 adalah dasar pengambilan keputusan dan diakhiri dengan rekomendasi. Metode yang digunakan dalam penelitian ini adalah metode Promethee (Preference Ranking Organization Method for Enrichment Evaluation).

Preference Ranking Organization Method for Enrichment Evaluation (Promethee) adalah metode penentuan urutan atau prioritas dalam analisis multikriteria. Dengan pertimbangan yang tepat, metode ini bisa menjadi salah satu alat untuk menentukan kebijakan bagi Perguruan tinggi dalam sistem pengambilan keputusan, khususnya dalam menentukan penerima bantuan dana pendidikan berupa zakat. Penentuan kebijakan diambil sebagai dasar dalam pengambilan keputusan, harus menggunakan kriteria yang dapat terdefinisi secara jelas dan objektif.

\section{A. Sistem Pendukung Keputusan}

Tidak ada definisi yang tepat dari SPK.[1], Finlay [2] mencoba untuk mendefinisikan SPK sebagai sebuah sistem berbasis komputer yang membantu proses pengambilan keputusan. Turban [1] mendefinisikan SPK sebagai sistem informasi berbasis komputer yang adaptif, interaktif dan fleksibel yang secara khusus dikembangkan untuk mendukung solusi dari masalah manajemen yang tidak terstruktur untuk meningkatkan kualitas pengambilan keputusan. SPK merupakan sistem berbasis komputer yang dapat membantu dalam proses pengambilan keputusan. Beberapa penelitian tentang sistem pendukung keputusan penentuan beasiswa sudah dilakukan, diantaranya penentuan penerima beasiswa dengan menggunakan metode TOPSIS FMADM [3] metode ini juga melakukan perankingan dengan mengubah data ke dalam bilangan fuzzy terlebih dahulu. Selanjutnya penelitian penggabungan metode AHP dengan Promethee dengan memilih kriteria pada metode AHP dan melakukan perankingan dengan metode Promethee [4]

\section{B. Zakat}

Zakat adalah bagian tertentu dari harta yang harus dikeluarkan diantara semua harta yang memenuhi persayaratan yang telah ditetapkan oleh setiap muslilm. Sebagai salah satu rukun islam, zakat dikeluarkan untuk diberikan bagi yang berhak mendapatkannya. Disebutkan dalam Al-quran "Ambilah zakat dari sebagian harta mereka, dengan zakat itu kamu membersihkan dan menyucikan mereka" (QS. At-Taubah :103). Zakat dikeluarkan dari harta yang dimiliki.akan tetapi, tidak semua harta terkena kewajiban zakat. Syarat dikenakan zakat atas harta di antaranya adalah:

1. Harta tersebut merupakan barang halal dan diperoleh dengan cara yang halal

2. Harta tersebut dimiliki oleh pemiliknya

3. Harta tersebut dapat berkembang

4. Harta tersebut mencapai nishab sesuai jenis hartanya

5. Harta tersebut melewati Haul dan

6. Pemilik harta tidak memiliki hutang jangka pendek yang harus dilunasi. [5]

\section{Promethee}

Promethee (Preference Ranking Organization for Enrichment Evaluation) adalah suatu metode penentuan urutan (prioritas) dalam analisis multikriteria, kesederhanaan, kejelasan dan kestabilan, merupakan masalah pokok promethee. Asumsi dominasi kriteria yang digunakan dalam promethee adalah penggunaan nilai dalam hubungan perangkingan [6].

Metode Promethee termasuk ke dalam kelompok pemecahan masalah Multi Criteria Decision Making (MCDM) atau pengambilan keputusan kriteria majemuk yang merupakan disiplin ilmu yang sangat penting dalam pengambilan keputusan atau suatu masalah yang memiliki lebih dari satu kriteria (multikriteria) [7].

Langkah langkah yang digunakan metode ini adalah sebagai berikut:

1. Mengidentifikasi alternatif.

2. Alternatif (a) dilakukan evaluasi pada kriteria (k), sehingga diperoleh kriteria yang harus dimaksimalkan atau kriteria yang harus diminimalkan.

3. Rekomendasi referensi model sistem dalam promethee disajikan 6 fungsi kriteria. Hal ini tidak mutlak, tetapi cukup baik untuk diterapkan dalam beberapa kasus. 
4. Evaluasi matriks. Saat kriteria alternatif sudah terpilih, langkah selanjutnya adalah membuat matriks hasil. Tabel matriks ini untuk setiap pasangan kriteria.

5. Menentukan indeks referensi multi kriteria. Referensi dinyatakan dengan angka antara 0 dan 1 dan di nilai dengan prosedur tertentu.

6. Promethee ranking. Arah dalam grafik nilai perankingan ditentukan berdasarkan leaving flow dan entering flow. Leaving flow adalah jumlah nilai garis lengkung yang memiliki arah menjauh dari node a dan hal ini merupakan karakter pengukuran perangkingan. Penjelasan dari hubungan perangkingan dibangun atas pertimbangan untuk aksi pada grafik nilai perangkingan, berupa urutan parsial (promethee I) dan urutan lengkap (promethee II) pada aksi yang mungkin, yang dapat diusulkan pada pembuatan keputusan untuk memperbanyak penyelesaian masalah karakteristik data [8].

\section{METODE PENELITIAN}

Penelitian ini merupakan jenis penelitian terapan yang bertujuan untuk menyelesaikan suatu permasalahan dengan menerapkan suatu metode matematika dalam memilih mahasiswa penerima bantuan.

\section{A. Pengumpulan Data}

Tahap ini dimulai dengan pengumpulan data yang terdiri dari studi pustaka dan riset lapangan. Data yang dikumpulkan berupa data mahasiswa berprestasi dan kurang mampu yang sudah mendaftarkan diri ke pengajuan beasiswa UPZ. Kemudian, mengidentifikasi syarat-syarat seperti IPK > 3,0, penghasilan orang tua di bawah rata-rata, mahasiswa 3-7, memiliki surat keterangan tidak mampu, berprestasi dan aktif ORMAWA, dan jumlah saudara. Jika mahasiswa memenuhi syarat, maka akan masuk ke dalam data input calon penerima zakat.

\section{B. Pengolahan Data}

Setelah melengkapi data, selanjutnya dilakukan pengolahan data, yaitu pengelompokkan masingmasing kriteria sesuai dengan preferensi dan menghitung nilai preferensinya sesuai metode Promethee.

\section{Perancangan Model}

Pada tahap ini peneliti melakukan analisis kebutuhan sistem, kemudian melakukan perancangan model sistem berdasarkan hasil analisis kebutuhan sistem. Penelitian ini masih dalam perancangan awal untuk membuat sistem sederhana, karena proses awal dalam identifikasi syarat sampai dengan perhitungan referensi masih dilakukan secara manual.

\section{Implementasi}

Perolehan data diimplementasikan ke dalam sistem, sehingga dapat diperoleh hasil yang diinginkan berupa mahasiswa yang berhak mendapatkan bantuan dana pendidikan berupa zakat.

\section{HASIL DAN DISKUSI}

\section{A. Analisis dan Perancangan Sistem}

Pada penelitian ini membahas tentang sistem pendukung keputusan yang berfungsi untuk mendukung pengambilan keputusan menentukan mahasiswa yang layak untuk mendapatkan bantuan dana pendidikan berupa zakat dengan menggunakan metode Promethee.

Kriteria yang ditetapkan dalam menentukan mahasiswa yang layak untuk menerima zakat adalah :

1. Memiliki IPK diatas 3,0

2. Penghasilan orang tua dibawah rata rata

3. Mahasiswa semester $3-7$

4. Memiliki Surat Keterangan Tidak Mampu

5. Berpretasi dan Aktif dalam Ormawa

6. Jumlah Saudara

Untuk mendapatkan hasil dalam menentukan pemilihan mahasiswa yang layak menerima zakat, maka dibuat suatu model sistem yang dapat menentukan urutan (prioritas) dalam analisis multikriteria yang dapat memberikan informasi tentang pemilihan mahasiswa yang layak menerima zakat. Tahapannya disajikan pada gambar 1 .

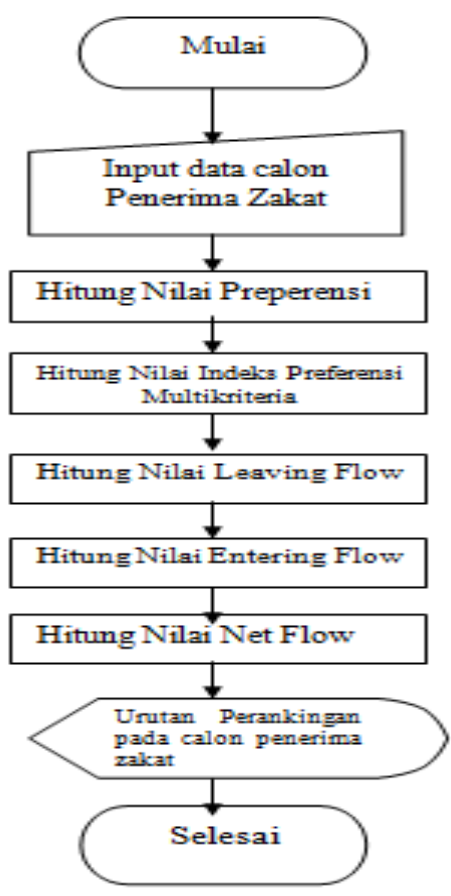

Gbr. 1 Flowchart Menentukan Prioritas Penerima Zakat 


\section{B. Kriteria Yang dibutuhkan}

Berikut merupakan kriteria yang dibutuhkan untuk pengambilan keputusan berdasarkan persyaratan beasiswa secara umum. Adapun kriteria yang telah ditentukan yaitu Nilai IPK

Page|158 (C1), Penghasilan orang tua (C2), Berprestasi dan Aktif dalam Ormawa (C3), dan Jumlah Saudara (C4)

Berdasarkan kriteria dan rating kecocokan setiap alternatif pada setiap kriteria yang telah ditentukan, selanjutnya penjabaran bobot setiap kriteria yang telah dikonversikan kedalam pembobotan 1-5.

\section{1) Kriteria nilai IPK}

Kriteria IPK merupakan persyaratan yang dibutuhkan untuk pengambilan keputusan, berdasarkan jumlah nilai IPK yang diperoleh oleh mahasiswa selama studi berlangsung. Berikut interval nilai IPK di bawah ini

TABEL I
NILAI IPK
\begin{tabular}{|l|l|}
\hline NILAI IPK & NILAI \\
\hline IPK $>3.00-<=3.20$ & 1 \\
\hline IPK $>3.20-<=3.40$ & 2 \\
\hline IPK $>3.40-<=3.60$ & 3 \\
\hline IPK $>3.40-<=3.80$ & 4 \\
\hline IPK $>3.80$ & 5 \\
\hline
\end{tabular}

\section{2) Kriteria Penghasilan Orang tua}

Kriteria penghasilan orangtua merupakan persyaratan yang dibutuhkan untuk pengambilan keputusan, berdasarkan jumlah penghasilan tetap maupun tidak setiap bulannya. Berikut penjabaran interval jumlah penghasilan orangtua dibawah ini.

TABEL II

PENGHASILAN ORANG TUA

\begin{tabular}{|l|l|}
\hline Penghasilan Orang tua $(\mathrm{x})$ & Nilai \\
\hline $0<=\mathrm{x}<=500.000$ & 5 \\
\hline $500.000<=\mathrm{x}<1.000 .000$ & 4 \\
\hline $1.000 .000<=\mathrm{x}<1.500 .000$ & 3 \\
\hline $1.500 .000<=\mathrm{x}<=2.000 .000 .-$ & 2 \\
\hline $\mathrm{x}>2.000 .000$ & 1 \\
\hline
\end{tabular}

3) Kriteria jumlah saudara

Kriteria jumlah saudara merupakan persyaratan yang dibutuhkan untuk pengambilan keputusan, berdasarkan jumlah anak yang masih menjadi tanggungan orangtua berupa biaya hidup. Berikut penjabaran jumlah saudara disajikan dalam tabel di bawah ini.
TABEL III

JUMLAH TANGGUNGAN ORANG TUA

\begin{tabular}{|c|c|}
\hline Jumlah Bersaudara & Nilai \\
\hline 1 Orang ( Tunggal) & 1 \\
\hline 2 orang & 2 \\
\hline 3 orang & 3 \\
\hline 4 Orang & 4 \\
\hline 5 Orang atau lebih & 5 \\
\hline
\end{tabular}

\section{4) Kriteria Berprestasi dan Aktif dalam} Ormawa

Kriteria mengikuti organisasi kemahasiswaan merupakan syarat yang dibutuhkan untuk pengambilan keputusan, berdasarkan mengikuti atau tidaknya serta menjadi pengurus atau sebagai anggota dalam suatu organisasi kemahasiswaan. Berikut penjabaran interval disajikan dalam tabel dibawah ini:

TABEL IV

BERPRESTASI DAN AKTIF

\begin{tabular}{|l|c|}
\hline Berprestasi dan Mengikuti Ormawa & Nilai \\
\hline $\begin{array}{l}\text { Berprestasi dan aktif sebagai pengurus } \\
\text { Ormawa }\end{array}$ & 5 \\
\hline Berprestasi dan menjadi Anggota & 4 \\
\hline Aktif sebagai pengurus Ormawa & 3 \\
\hline Menjadi Anggota Ormawa & 2 \\
\hline $\begin{array}{l}\text { Tidak berpretasi dan tidak mengikuti } \\
\text { ormawa }\end{array}$ & 1 \\
\hline
\end{tabular}

Selanjutnya, dilakukan langkah-langkah menentukan bobot kriteria, yaitu:

a. Menentukan notasi untuk setiap kriteria Notasi yang digunakan dalam kriteria tersebut adalah :

C1 : IP mahasiswa

$\mathrm{C} 2$ : Penghasilan orang tua

C3 : Berprestasi dan aktif berogranisasi

C4 : Jumlah Saudara

b. Menentukan notasi alternatif yang digunakan Notasi alternatif yang digunakan adalah:

A1 : Ali

A2 : Debi

A3 : Intan

A4 : Iqwa

A5 : Maulidya

c. Menentukan notasi hasil perhitungan

Notasi hasil perhitungan :

$\mathrm{LF}$ : Leaving flow

$\mathrm{EF}$ : Entering flow

$\mathrm{NF}:$ Net flow

Berikut ini, adalah data mahasiswa yang mengajukan untuk mendapatkan dana bantuan Pendidikan berupa zakat dari UPZ UINSU, untuk Program Studi Matematika: 
TABEL $V$

DATA MAHASISWA

\begin{tabular}{|c|l|c|c|c|c|c|}
\hline \multirow{2}{*}{ No. } & \multirow{2}{*}{ Kriteria } & \multicolumn{5}{|c|}{ Nilai } \\
\cline { 3 - 7 } & \multicolumn{2}{|l|}{ Ali } & Debi & Intan & Iqwa & Maulidya \\
\hline 1. & IP & 3,28 & 3.82 & 3,4 & 3,30 & 3,35 \\
\hline 2. & Penghasilan orang tua & 1.800 .000 & 1.750 .000 & 3.000 .000 & 2.000 .000 & 500.000 \\
\hline 3. & $\begin{array}{l}\text { Berprestasi dan aktif } \\
\text { berorganisasi }\end{array}$ & $\begin{array}{c}\text { Aktif } \\
\text { organisasi }\end{array}$ & Tidak & $\begin{array}{c}\text { Aktif } \\
\text { Organisasi }\end{array}$ & Tidak & Tidak \\
\hline 4. & Jumlah saudara & 5 & 4 & 4 & 2 & 1 \\
\hline
\end{tabular}

Berdasarkan data mahasiswa diatas dapat dibentuk matriks keputusan $\mathrm{X}$, sebagai berikut :

TABEL. VI NILAI BOBOT KRITERIA

\begin{tabular}{|c|l|c|c|c|c|c|}
\hline No. & \multirow{2}{*}{ Kriteria } & \multicolumn{5}{|c|}{ Nilai } \\
\cline { 3 - 7 } & & A1 & A2 & A3 & A4 & A5 \\
\hline 1. & C1 & 2 & 5 & 2 & 2 & 2 \\
\hline 2. & C2 & 2 & 2 & 1 & 2 & 5 \\
\hline 3. & C3 & 3 & 1 & 3 & 1 & 1 \\
\hline 4. & C4 & 5 & 4 & 4 & 2 & 1 \\
\hline
\end{tabular}

Setelah menyusun nilai bobot kriteria dalam tabel, pertama sekali yang dilakukan adalah menentukan nilai deviasi. Menentukan nilai deviasi berdasarkan nilai bobot yang telah ditentukan pada tabel dari N1 sampai N4. Nilai Deviasi dirancang untuk menghasilkan nilai fungsi yang berbeda antara dua nilai evaluasi, sehingga: [4]

$P(A, B)=P\{f(A)-f(B)\}$

Keterangan :

$\begin{array}{ll}\mathrm{C} & =\text { Alternatif C } \\ \mathrm{D} & =\text { Alternatif } \mathrm{D} \\ \mathrm{P}(\mathrm{A}, \mathrm{B}) & =\text { Preference index alternatif A } \\ & \text { terhadap alternatif } \mathrm{B} \\ \mathrm{F}(\mathrm{A}) & =\text { Nilai fungsi alternatif } \mathrm{A} \\ \mathrm{F}(\mathrm{B}) & =\text { Nilai fungsi alternatif } \mathrm{B}\end{array}$

\section{Nilai Deviasi $d_{\mathbf{j}}(\mathbf{1 , 2})$}

$\mathrm{d}_{\text {indeks prestasi }}(1,2)=2-5=-3$; kuasi, $\mathrm{H}(\mathrm{d})=0$

$\mathrm{d}_{\text {penghasilan }}(1,2)=2-2=0$; kuasi linier $i ; \mathrm{H}(\mathrm{d})=0$

$\mathrm{d}_{\text {prestasi dan aktif }}(1,2)=3-1=2$; preferensi linear $; \mathrm{H}(\mathrm{d})=$ 1

$\mathrm{d}_{\text {jumlah saudara }} \quad(1,2)=5-4=1$; kuasi linear $; \mathrm{H}(\mathrm{d})=0$

$$
\mathrm{H}\left(\mathrm{d}_{\mathrm{j}}(1,2)=\frac{1}{4} \times(0+0+1+0)=0.25\right.
$$

Perhitungan terus dilakukan untuk menentukan nilai deviasi yang lain, setelah selesai melakukan perhitungan nilai deviasi maka selanjutnya melakukan perhitungan nilai Leaving flow. Nilai Leaving flow bertujuan untuk melakukan perhitungan ranking dengan menentukan nilai positif. Dengan memasukkan hasil nilai deviasi terlebih dahulu yang telah dicari dengan menggunakan rumus yang telah ditentukan.

\section{Perhitungan Nilai Leaving flow}

Nilai Leaving flow adalah jumlah dari arah yang menjauh dari node a dan hal ini merupakan pengukuran perangkingan. Untuk menentukan Nilai Leaving flow menggunakan rumus :

$\phi^{+}=\frac{1}{n-1} \sum x \in A \varphi(a, x)$

Keterangan :

$$
\begin{aligned}
& \emptyset^{+}=\text {nilai Leaving flow } \\
& \mathrm{a}=\text { yang berkaitan dengan alternatif } \\
& \mathrm{n}=\text { alternatif }
\end{aligned}
$$

\section{Perhitungan Leaving flow $A_{1}$}

$$
\begin{aligned}
\varphi_{1}^{+} & =\frac{1}{(5-1)} \times(0,25+0+0,5+0.5) \\
\varphi_{1}^{+} & =\frac{1}{4} \times(1.25) \\
\varphi_{1}^{+} & =0.3125
\end{aligned}
$$

Setelah selesai melakukan perhitungan nilai Leaving flow, langkah selanjutnya menghitung nilai Entering flow. Nilai Entering flow bertujuan untuk melakukan perhitungan ranking dengan mencari nilai negatif. Dengan memasukkan hasil dari nilai deviasi yang sudah dicari terlebih dahulu dengan rumus yang telah ditentukan.

\section{Perhitungan Nilai Entering flow}

Nilai Entering flow adalah jumlah dari arah yang mendekat dari node a dan hal ini merupakan 
pengukuran perangkingan. Untuk menentukan Nilai Entering flow menggunakan rumus :

$\phi^{-}=\frac{1}{n-1} \sum x \in A \varphi(a, x)$

Page | 160 Keterangan :

$$
\begin{aligned}
& \emptyset=\text { nilaiLeaving flow } \\
& \mathrm{a}=\text { yang berkaitan dengan alternatif } \\
& \mathrm{n}=\text { alternatif }
\end{aligned}
$$

\section{Perhitungan Entering flow $\mathrm{A}_{1}$}

$$
\begin{aligned}
& \varphi_{1}^{-}=\frac{1}{(5-1)} \times(0,25-0-0,5-0.5) \\
& \varphi_{1}^{-}=\frac{1}{4} \times(-0.75) \\
& \varphi_{1}^{-}=-0.1875
\end{aligned}
$$

\section{Menghitung Nilai Net Flow}

Penilaian secara lengkap maksudnya yaitu penilaian yang didapat dari nilai entering flow yang dikurangi nilai leaving flow. Dapat diartikan, nilai net flow adalah nilai akhir atau hasil yang didapat dari nilai positif yang dikurangi nilai negatif dari sebuah node.

$\phi(a)=\phi^{+}(a)-\phi^{-}(a)$

Dimana $\varnothing$ adalah net flow digunakan untuk menghasilkan keputusan akhir penentuan urutan dalam menyelesaikan masalah sehingga menghasilkan urutan lengkap.

\section{Perhitungan Nilai Net Flow A1}

$$
\begin{aligned}
& \varphi_{(1)}=\varphi_{(1)}^{+}-\varphi_{(1)}^{-} \\
& \varphi_{(1)}=0.3125+0.1875 \\
& \varphi_{(1)}=0.5
\end{aligned}
$$

Setelah semua perhitungan selesai dilakukan dan mendapatkan hasilnya, maka tahap selanjutnya yaitu perankingan. Perankingan inilah yang menentukan mahasiswa manakah yang akan mendapatkan beasiswa. Mahasiswa yang mendapatkan rangking 1 memiliki kemungkinan terbesar untuk mendapatkan beasiswa. Sedangkan, mahasiswa yang mendapatkan rangking terakhir memiliki kemungkinan terkecil untuk mendapatkan beasiswa.

\section{Perankingan}

Ranking 1: $\mathrm{A}_{3}=0.6$

Ranking 2: $\mathrm{A}_{1}=0.5$

Ranking 3: $\mathrm{A}_{4}=0.33375$

Ranking 4: $\mathrm{A}_{2}=0.20875$

Ranking 5: $\mathrm{A}_{5}=0.125$

Setelah kita lihat hasil dari perankingan di atas, maka dapat diketahui bahwa rangking 1 yaitu mahasiswa yang bernama Intan. Ini menunjukkan bahwa mahasiswa pertama yang memiliki kemungkinan terbesar mendapatkan beahasiswa ialah Intan dengan hasil perangkingan 0,6. Sedangkan, mahasiswa kedua yang kemungkinan mendapatkan beasiswa adalah rangking 2 dengan mahasiswa yang bernama Ali. Hasil perangkingan yang diperoleh yaitu 0.5. Kemudian, mahasiswa ketiga yang kemungkinan mendapatkan beasiswa ialah yang rangking 3 yaitu Iqwa. Dengan hasil perangkingan 0.33375. Untuk mahasiswa keempat yang memiliki kemungkinan mendapat mendapatkan beasiswa yaitu rangking 4 dengan mahasiswa yang bernama Debi. Hasil perangkingan yang diperolehnya yaitu 0.20875. Terakhir, yang memiliki kemungkinan terkecil untuk mendapat beasiswa yaitu rangking 5 dengan mahasiswa yang bernama Maulidya. Hasil perangkingan yang diperolehnya yaitu 0.125 .

\section{Desain Fungsional}

Penelitian ini masih menggunakan sistem manual dan sederhana yang membantu menyelesaikan permasalahan pemilihan mahasiswa penerima bantuan. Pada tahap selanjutnya diharapkan dapat dibangun suatu sistem aplikasi berbasis web maupun android yang tidak lagi menggunakan cara manual dalam identifikasi syarat atau kriteria penerima bantuan seperti yang digambarkan pada diagram alir (flowchart) berikut yang merupakan hasil pengembangan diagram alir sebelumnya. 


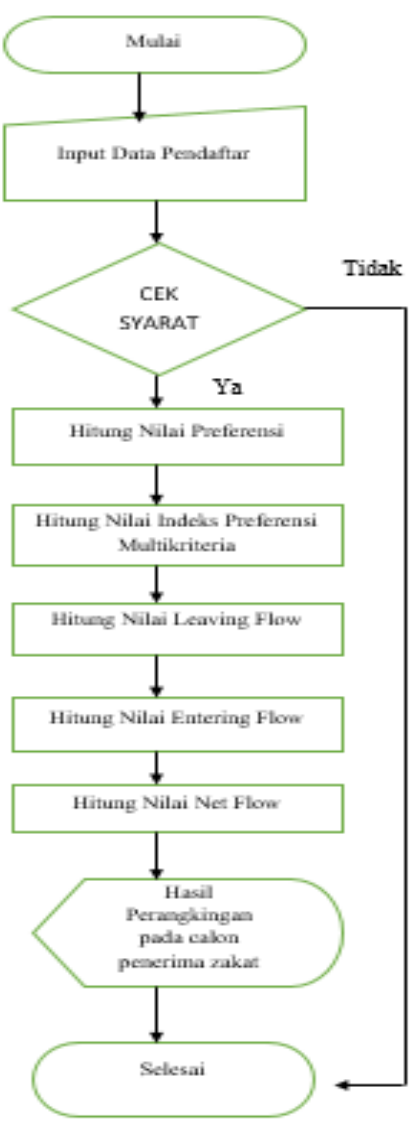

Gbr.2 Flowchart yang dikembangkan untuk sistem

\section{KESIMPULAN}

Permasalahan penentuan penerima bantuan zakat oleh mahasiswa dapat diselesaikan dengan menggunakan metode PROMETHEE. Metode ini tepat untuk menentukan penerima bantuan zakat yang dimulai dengan proses pemberian nilai preferensi pada kriteria kemudian menghitung indeks preferensi multikriteria. Berdasarkan indeks preferensi multikriteria dapat dihitung nilai yang menjauhi node negatif dan mendekati node positif dan dihitung selisih diantara keduanya (net). Hasil menunjukkan nama penerima bantuan pendidikan (zakat) yang prioritas.

Berdasarkan hasil yang diperoleh dari penelitan ini maka mahasiswa yang layak menerima bantuan zakat adalah Intan, mahasiswa semester 5(lima) dengan hasil perangkingan 0,6

\section{REFERENSI}

[1] R. Aprilia, Triase and Sriani. "Penentuan Tempat Menginap Dengan Menggunakan Fuzzy Multiple Attribute Decision Making." Algoritma: jurnal ilmu komputer dan informatika, 2017, vol.1. No.01.

[2] R. Aprilia. "Fuzzy Multiple Attribute Decision Making In Hotel Selection." Zero: Jurnal Sains, Matematika dan Terapan, 2019, vol. 2 no. 2 .

[3] Husein, Ismail and D. Juliandri. "Decision Support System For Determining Scholarship Recipients Using Topsis FMADM Method." ZERO: Jurnal Sains, Matematika dan Terapan, 2017, vol.1 no.1.

[4] R. Widyasari, H. Cipta, and A. H. Hasugian.” Developing Fuzzy-Promethee Methods by Using AHP Method On Student Achieving Selection". IJISTECH: Journal of Information System and Technology, 2020, Vol. 3 No.2.

[5] 2020. Baznas website [online]. Available: Baznas.go.id/zakat

[6] I. Taufik, U. Syaripudin and Jumadi. "Implementasi Metode Promethee Untuk Menentukan Penerima Beasiswa." 2017, Vol.X, No.1, pp. 124-138.

[7] Hafsah, F. R. Kodong, and A. Julian. "Sistem Pendukung Keputusan Penentuan Hotel Dengan Menggunakan Metode Promethee dan AHP. "Seminar Nasional Informatika (SEMNASIF). 2015" Vol. 1. No. 4.

[8] T. Imandasari, A. Wanto, A. P. Windarto. Analisis Pengambilan Keputusan Dalam Menentukan Mahasiswa PKL Menggunakan Metode Promethee. JURIKOM (Jurnal Riset Komputer),2018, Vol.5. No.3, pp. 234-239. 